\title{
Examining causality between market share and competitiveness: case study textile industry
}

DOI: 10.35530/IT.071.04.1727

NIKOLA V. ĆURČIĆ

NIKOLA RADIVOJEVIĆ

ALEKSANDAR GRUBOR

ZORAN D. SIMONOVIĆ

\section{ABSTRACT - REZUMAT}

\section{Examining causality between market share and competitiveness: case study textile industry}

The paper dealt with the existence of causality in Granger's sense between competitiveness and market share, and vice versa, on emerging markets so as to answer the question whether it is possible to forecast the movement of the market share of an enterprise based on the data about the movement of the competitiveness of that enterprise. The research study was carried out on 96 textile companies from Serbia, Montenegro, and Bosnia and Herzegovina. The results of research have shown that relationship between competitiveness and market share is generally weak and in many industrial sectors it is nonexistent. In other words, the research results reveal that the existence of causality in Granger's sense between competitiveness and market share on the selected emerging markets depends on the branch of textile industry.

Keywords: market share, competitiveness, emerging markers, Granger causality, textile industry

Analiza cauzalității dintre cota de piață și competitivitate: studiu de caz industria textilă

Lucrarea dezbate existența cauzalității în sensul lui Granger, între competitivitate și cota de piață, și viceversa, pe piețele emergente, astfel încât să răspundă la întrebarea dacă este posibil să se prevadă evoluția cotei de piață a unei întreprinderi bazată pe datele despre evoluția competitivității întreprinderii. Studiul de cercetare a fost realizat pe 96 de companii textile din Serbia, Muntenegru și Bosnia și Herțegovina. Rezultatele cercetărilor au arătat că relația dintre competitivitate și cota de piață este în general slabă și în multe sectoare industriale este inexistentă. Cu alte cuvinte, rezultatele cercetării demonstrează că existența cauzalității în sensul lui Granger între competitivitate și cota de piață pe piețele emergente selectate depinde de ramura industriei textile.

Cuvinte-cheie: cota de piață, competitivitate, markeri emergenți, cauzalitate Granger, industria textilă

\section{INTRODUCTION}

Relevant research studies show a strong connection and causality between market share and competitiveness. In business practice and academic circles, there is a widespread understanding that a big market share automatically implies a great market power and competitiveness. This conventional understanding is founded on the assumption that a profitable increase in the price in function of the improvement of an organization's business success is more likely to occur in the organizations which have a bigger than in those which have a smaller market share. For that reason, there is also a widespread and colloquial understanding that the growth of market share also means the growth of competitiveness and vice versa. Numerous studies carried out in the late $20^{\text {th }}$ and in the early $21^{\text {st }}$ centuries have been supportive of the attitude as this one, indicating that the majority of the organizations with a big market share were enjoying above-average profit margins and competitiveness. Some research studies conducted in the late 1980s, however, showed that the companies with a low market share could also be successful and competitive in certain environments, and that sometimes a fall in market share is also a result of a preconcerted policy to improve profitability and competitiveness. The summary conclusion of those research studies is indicative of certain limitations in a sense that the growth of the market share of organizations in different industries cannot serve as a recipe for an increase in competitiveness.

The fact that they were exclusively conducted on the markets of developed countries and that their conclusions relate to the organizations having been operating in mature industries is characteristic of the previously mentioned research studies. A very small number of the studies are dedicated to researching causality between the growth of market share and competitiveness on emerging markets [1]. Therefore, a question is posed if the conclusions of these research studies are also valid for emerging markets (transitory economies) on which numerous irregularities and regularities in the functioning of the market which are in opposition to the laws of Smith's "invisible hand".

For that reason, this paper is aimed at examining causality in Granger's sense between the movement 
of market share and the competitiveness of the organizations operating on emerging markets, such as the Serbian, Montenegrin and Bosnian-Herzegovinian economies are, so as to answer the question whether it is possible to forecast the profit movement on the basis of the market share movement, and vice versa.

\section{LITERATURE REVIEW}

There are a large number of the papers dealing with the study of the impact of market share on organizations' performances, i.e. their competitiveness. The first studies were done as early as in the 1970s and the 1980s. Some of the best-known studies of those times are the research studies conducted by Schoeffler et al. [2], Buzzell [3], Newton [4] etc. They show statistically relationship between market share and competitiveness and profitability.

Apart from these studies, however, research studies such as a research study by Hamermesh and Anderson [5], which refer to the conclusion that enterprises with small market shares can also achieve above-average profits. Similar conclusions were also reached by Chawla et al. [6], Chandler and Hanks [7].

There are also the studies that found no existence of any connection whatsoever between market share and competitiveness. Such research studies were carried out by Boulding and Staelin [8], Jacobson [9] and Wensley [10], Schmalensee [11], Mueller [12]. Jacobson [9] concluded that although there may be a direct relationship between market share and competitiveness, it may be a spurious relationship [13]. The results of research were conducted by Faria and Wellington [14] show the existence of a significantly and positively correlated relationship, but the strength of the relationship was not as strong as suggested by the PIMS findings. Amburgey et al. [15], Sheth and Sisodia [16] found the proofs in favor of the U-shaped relationship between these two variables. By applying panel analysis, Genchev [17] confirmed the positive connection between market share and competitiveness. Similar research studies were conducted by Etale, Bringilarz and Ifuruezes [18], Goddard et al. [19], Pattitoni et al. [20], Leverty [21]. The foregoing is indicative of the fact that although there are a large number of the papers dealing with the study of the relationship between market share and the competitiveness.

\section{THEORETICAL BACKGROUND OF THE ISSUE IN THE CONTEXT OF THE METHODOLOGY USED}

In the context of the subject matter of the research of this paper, the application of the Granger causality test would imply that based on a set of data on the movement of companies' market share it would be possible to forecast a future movement of companies' competitiveness better than only conducting such forecast on the basis of the time series of the historical data about the profit movement. In other words, on the assumption that there is an available set of information about the movement of the market share $(x)$ of a certain company and its competitiveness, which is expressed through profit $(y)$ at a certain moment $(t)$ (the information set $\left.\Omega_{t}\right)$ of the form $\left(x_{t}, \ldots\right.$, $\left.x_{t-j}, y_{t}, \ldots, y_{t-i}\right)$, the data about market share at the moment $(t)\left(x_{t}\right)$ can be said to be Granger-causal for the company's profit data $\left(y_{t}\right)$ wrt. $\Omega_{t}$ if the variance of the optimal linear predictor for predicting a profit at the moment $t+h\left(y_{t+h}\right)$, based on the available set of pieces of information at the moment $(t)\left(\Omega_{t}\right)$ has a smaller variance than the optimal linear predictor for $y_{t+h}$ only based on the data about the movement of the profit from the prior period, for any $h$. For the reason of the said, the data about the market share of a company $(x)$ can be said to Granger-cause $y$ if, and only if $\sigma_{1}^{2}\left(y_{t}: y_{t-j}, x_{t-i}\right)<\sigma_{2}^{2}\left(y_{t}: y_{t-j}\right)$, with $j$ and $i=1,2$, $3, \ldots, n$, and $\sigma^{2}$ representing the variance of the forecast error.

In this paper, the first type of the Granger causality test is used given the fact that the paper is aimed at examining whether it is possible to forecast a future movement of companies' profits on the basis of the data on their market share and vice versa.

Bearing in mind the foregoing, the following equations are tested in the paper:

$$
\begin{gathered}
M S_{t}=\alpha+\sum_{t=1}^{m} \beta_{i}(M S)_{t-i}+\sum_{j=1}^{n} \tau_{j}(P f)_{t-j}+\mu_{t} \\
P f_{t}=\theta+\sum_{t=1}^{p} \phi_{i}(P f)_{t-i}+\sum_{j=1}^{q} \psi_{j}(P f)_{t-j}+\eta_{t}
\end{gathered}
$$

where: $P f$ is the profit rate, $M S$ - market share rate, $\mu$ and $\eta-$ residuals which are assumed to $\mu$ and $\eta \sim$ IID $N(0,1)$.

Based on the written equations, the following four hypotheses are possible to test by applying the OLS estimator:

1. There is unidirectional causality from a change in market share towards a change in the profit rate, i.e. change in a company's market share increases the forecasting of change in the company's profit rate, but not vice versa, so that:

$$
\sum_{j=1}^{n} \tau_{j} \neq 0 \text { and } \sum_{j=1}^{q} \psi_{j}=0
$$

2. There is unidirectional causality from a change in the profit rate towards a change in a company's market share, i.e. change in the profit rate of the company increases the forecasting of change in its market share, but not vice versa, thus:

$$
\sum_{j=1}^{n} \tau_{j}=0 \text { and } \sum_{j=1}^{q} \psi_{j} \neq 0
$$

that there is bidirectional (or feedback) causality:

$$
\sum_{j=1}^{n} \tau_{j} \neq 0 \text { and } \sum_{j=1}^{q} \psi_{j} \neq 0
$$

This means that based on change in a company's market share it is possible to forecast change in the company's profit rate, and vice versa.

3. There is no Granger causality in any direction whatsoever, i.e. that: 


$$
\sum_{j=1}^{n} \tau_{j}=0 \text { and } \sum_{j=1}^{q} \psi_{j}=0
$$

By proving one of these theses enables us to answer the question: is it possible to reliably forecast a future movement of a company's profit rate based on the movement of or change in the company's market share on the selected developing markets (in transitory economies), and vice versa.

\section{EMPIRICAL ANALYSIS}

The research study includes 96 companies from Serbia, Montenegro, and Bosnia and Herzegovina. Apart from the fact that these three states are in a similar phase of the development of their respective economies, i.e. the transition process, the EU accession phase, similar legal regulations from within the economic field and that they all have a common historical economic heritage, it is also characteristic of them that a large number of the companies from these states simultaneously do business in all the three states. The data were collected for the period from 2005 to 2018 through the Business Registers Agency, or the Chambers of Commerce. The selected companies belong to the six popular branches of the textile industries namely: the wool industry, knitwear industry, the apparel industry, the footwear industry, the carpet industry and the artificial fiber industry and from IT sector of design of textile. For the reason of the protection of the data, the paper presents the data of only those companies for which consents were obtained, or whose data are publicly available according to the respective laws of these countries, simultaneously paying attention to the presenting of the sample (the presented data and results of the analysis) that will represent the overall results of the analysis as truly as possible. Competitiveness is expressed by the profit annual rate.

The first step in the application of the Granger causality test implied the examination of the stationarity of the time series and the determination of the number of the unit roots (the order of integration). For that purpose, the ADF test was used in the paper, mentioning that the $\sqrt[3]{T}$ rule, i.e. the application of the Bretl kernel, was used to determine the maximum lag. While applying the ADF test, attention was paid to whether a series had a trend and also if it oscillated around the constant or not. Such a situation is recorded in about $87 \%$ of the time series. Just slightly over one-third of the time series had a problem with non-stationarity, that being so almost in an equal number in both series. More exactly, in 35 examined companies, at least one of the time series had the non-stationarity problem in level data. In the seven companies, the series were still nonstationary after the application of the first difference technique. No sooner had the second-order differentiation been applied than these series became stationary. It is interesting that there were no examples of both series in the same company being nonstationary at the second level. In the case of 28 companies, both series were nonstationary at the same basic level.
The greatest number of the nonstationary series were recorded in the sector of the the footwear industry, which can also be explained by great instability in this sector as a consequence of the transition process that has had an influence on the liquidation and restructuring of a huge number of big companies from within this sector and the occurrence of a large number of smaller-sized companies, which continued to do business with different successes. In the case when the series were nonstationary at the same level, the cointegration test was done. For that purpose, the Engel-Granger cointegration test was used. Such an example was recorded in the TSS company from within the footwear industry, whose results of the Engel-Granger cointegration test as an adequate representative for this type of analysis are shown in table 1.

Table 1

THE RESULTS OF THE ENGEL-GRANGER COINTEGRATION TEST

Step 1. Cointegrating regression - OLS, using the observations from 2005 to $2018(T=14)$ Dependent variable: Profitability

\begin{tabular}{|l|c|c|c|c|}
\hline Indicator & Coefficient & Std. error & t-ratio & $p$-value \\
\hline Const. & 0.268 & 0.138 & 1.936 & $0.0767^{*}$ \\
\hline M. share & 0.275 & 0.280 & 0.983 & 0.345 \\
\hline \multicolumn{2}{|c|}{ R-squared } & 0.074 & $\begin{array}{c}\text { Adjusted } \\
\text { R-squared }\end{array}$ & -0.003 \\
\hline
\end{tabular}

Step 2: testing for a unit root in uhat, Augmented Dickey-Fuller test for uhat, testing down from 2 lags, criterion AIC, the sample size 12; unit-root null hypothesis: $\mathrm{a}=1$

\begin{tabular}{|l|c|}
\hline model: $(1-\mathrm{L}) \mathrm{y}=(\mathrm{a}-1)^{*} \mathrm{y}(-1)+\ldots+\mathrm{e}$ \\
\hline estimated value of $(\mathrm{a}-1):$ & -1.319 \\
\hline test statistic: tau_c(2) & -3.767 \\
\hline asymptotic p-value & 0.015 \\
\hline 1st-order autocorrelation coefficient for e: & 0.083
\end{tabular}

Note: The length of the lag was chosen in the same manner as in the case of the ADF test, mentioning that a test-down from the maximum lag order was done.

The results of the Engel-Granger cointegration test indicate the existence of cointegration for the significance level of $1 \%$. Such a result was recorded in $13.54 \%$ of the examined companies. According to Sim, Stock and Watson (1990), in the case of the presence of cointegration between the variables the VECM model was used instead of the VAR model. The results of the VECM model on the example of this company are accounted for in table 3 below.

The second step in the application of the Granger causality test implied the determination of the optimal lag length. In the majority of the prior research studies, the lag length was arbitrarily determined. More recent research studies, however, have been emphasizing the significance of the regular determination of the lag length. Therefore, the three information criteria - namely the Akaike criterion, the Schwarz Bayesian 


\begin{tabular}{|c|c|c|c|c|c|}
\hline \multicolumn{6}{|c|}{ THE RESULTS OF THE GRANGER CASUALIITY TEST IN THE VAR MODELS } \\
\hline \multirow{2}{*}{ Company name } & \multirow{2}{*}{$\begin{array}{l}\text { Hypothesis } \\
\left(\mathrm{H}_{0,1}, \mathrm{H}_{0,2}\right)\end{array}$} & \multirow{2}{*}{ Stat. } & \multirow{2}{*}{ p-value } & \multicolumn{2}{|c|}{ p-value } \\
\hline & & & & Autocorr. & $\mathrm{ARCH}$ \\
\hline \multirow{2}{*}{ Wool industry Ltd } & Pf does not Granger-cause MS & $F(2,7)=0.767$ & 0.500 & \multirow{2}{*}{0.530} & \multirow{2}{*}{0.868} \\
\hline & MS does not Granger-cause Pf & $F(2,7)=0.839$ & 0.471 & & \\
\hline \multirow{2}{*}{ Ovium Ltd } & Pf does not Granger-cause MS & $F(2,7)=0.745$ & 0.509 & \multirow{2}{*}{0.380} & \multirow{2}{*}{0.477} \\
\hline & MS does not Granger-cause Pf & $F(2,7)=1.199$ & 0.357 & & \\
\hline \multirow{2}{*}{ Knitwear industry Ltd } & Pf does not Granger-cause MS & $F(2,7)=3.006$ & 0.114 & \multirow{2}{*}{0.444} & \multirow{2}{*}{0.938} \\
\hline & MS does not Granger-cause Pf & $F(2,7)=1.744$ & 0.243 & & \\
\hline \multirow{2}{*}{ Becomlabs Ltd } & Pf does not Granger-cause MS & $F(3,4)=0.717$ & 0.591 & \multirow{2}{*}{0.463} & \multirow{2}{*}{0.544} \\
\hline & MS does not Granger-cause Pf & $F(3,4)=6.309$ & 0.054 & & \\
\hline \multirow{2}{*}{$\begin{array}{l}\text { Artificial fiber industry } \\
\text { Ltd }\end{array}$} & Pf does not Granger-cause MS & $F(1,10)=0.021$ & 0.888 & \multirow{2}{*}{0.847} & \multirow{2}{*}{0.866} \\
\hline & MS does not Granger-cause Pf & $F(1,10)=0.357$ & 0.563 & & \\
\hline \multirow{2}{*}{ Apparel industry Ltd } & Pf does not Granger-cause MS & $F(2,7)=2.568$ & 0.146 & \multirow{2}{*}{0.380} & \multirow{2}{*}{0.477} \\
\hline & MS does not Granger-cause Pf & $F(2,7)=2.260$ & 0.175 & & \\
\hline
\end{tabular}

Note: In the last two columns in the table, the p-values of the autocorrelation test and the ARCH effect of the tested VAR models are shown. Autocorrelation and the presence of the $\mathrm{ARCH}$ effect is not recorded in one single company, which clearly indicates the correctness of the VAR models. $\mathrm{H}_{0,1} \mathrm{H}_{0,2}$ are the null hypotheses for the first, or the second variable, respectively.

criterion, and the Hannan-Quinn criterion - were used in the paper for that purpose. Given the fact that these criteria can generate different lag lengths, when making a selection between them, attention was paid to the fact that the choice of the optimal lag length should be a compromise between the lag length and the number of the parameters since it is known that the number of the parameters in the system quickly grows as the length increases, whereas, on the other hand, a small lag length can lead to a misspecification problem. The optimal lag length was mainly 2 . In the case of 14 companies, according to the given criteria, the optimal lag length was 3, whereas 13 had the optimal lag 1 .

Table 2 accounts for the results of the Granger causality test in the VAR models, whereas table 3 accounts for the results of the VECM model of the selected company. Based on the results shown in table 2, it is possible to notice that in the largest number of the cases it was recorded that the series do not Granger-cause one another. The analysis of the application of the VECM model indicates that it was found in the majority of the cases (in 7 companies) that the residual was statistically significant for the competitiveness variable, which means that competitiveness is not weakly exogenous and that it moves to restore the equilibrium with the market share variable, when the system is out of balance, and that in the case of the second variable the residual is not statistically significant, which means that the second variable is weakly exogenous and that it does not move to restore the equilibrium with the competitiveness variable. The reversed situation was recorded in the case of three companies. In one case, it both residuals were recorded to be statistically significant, namely in the apparel industry, whereas in the other
Table 3

\begin{tabular}{|c|c|c|c|c|}
\hline \multicolumn{5}{|c|}{ THE RESULTS FOR THE VEC MODEL } \\
\hline \multicolumn{5}{|c|}{ 2007-2018 (T = 12) } \\
Dependent variable: d_v1 \\
(the first difference of profitability) \\
\hline Indicator & Coefficient & Std. error & t-ratio & p-value \\
\hline d_v2_1 & -0.351 & 0.2183 & -1.606 & 0.143 \\
\hline e_1 & -1.249 & 0.348 & -3.587 & $0.006^{* * *}$ \\
\hline d_v1_1 & 0.607 & 0.306 & 1.982 & $0.079^{*}$ \\
\hline F(3,9) & 4.611 & - & P-value(F) & 0.032 \\
\hline \multicolumn{5}{|c|}{ Andjela Ltd: OLS, using the observations for } \\
$2006-2018$ (T = 13) \\
\hline \multicolumn{5}{|c|}{ (the first difference of market share) } \\
\hline Indicator & Coefficient & Std. error & t-ratio & p-value \\
\hline d_v1_1 & -0.048 & 0.436 & -0.109 & 0.915 \\
\hline e_1 & 0.249 & 0.496 & 0.504 & 0.627 \\
\hline d_v2_1 & -0.463 & 0.311 & -1.489 & 0.171 \\
\hline F(3, 9) & 0.988 & - & P-value(F) & 0.441 \\
\hline
\end{tabular}

cases, the residuals for both variables were recorded not be statistically significant.

The summary account of the tested hypotheses and their possible combinations as per the sectors is presented in table 4.

As can be seen from the table 4 , in the largest number of the cases (even in 44), there is no variable influencing the movement of the other one, which means that based on their movement, the movement of the other one is impossible to forecast, as is assumed by the premise on which the Grangercausality test was built. There is a reverse situation in 
THE SUMMARY ACCOUNT OF THE TESTED HYPOTHESES AND THEIR POSSIBLE COMBINATIONS AS PER THE SECTORS

\begin{tabular}{|c|c|c|c|c|c|c|c|}
\hline Sector & $\mathrm{H}_{0,1}$ and $\mathrm{H}_{0,2}$ & $\mathrm{H}_{0,1}$ and $\mathrm{H}_{1,2}$ & $\mathrm{H}_{1,1}$ and $\mathrm{H}_{0,2}$ & $\mathrm{H}_{1,1}$ and $\mathrm{H}_{1,2}$ & $\begin{array}{l}\text { Sum of } \\
\text { comp. }\end{array}$ & Hypoth.* & Hypoth.** \\
\hline The wool industry & 1 & 7 & 4 & - & 12 & -1.224 & 0.508 \\
\hline The carpet industry & 9 & 4 & 3 & 1 & 17 & -2.266 & -1.781 \\
\hline The knitwear industry & 7 & 5 & 1 & - & 13 & -3.124 & -0.904 \\
\hline The footwear idnustry & 9 & 1 & 1 & - & 11 & -2.780 & -2.780 \\
\hline The artificial fiber industry & 11 & 2 & - & - & 13 & -3.678 & -2.569 \\
\hline The apparel industry & 5 & 6 & 3 & 1 & 15 & -1.885 & -0.336 \\
\hline $\begin{array}{l}\text { IT industry of design of } \\
\text { textile }\end{array}$ & 2 & 9 & 1 & 3 & 15 & -1.885 & 2.247 \\
\hline Total & 44 & 34 & 13 & 5 & 96 & -6.321 & -2.033 \\
\hline
\end{tabular}

Note: $\mathrm{H}_{0,1}, \mathrm{H}_{0,1}, \mathrm{H}_{0,2}, \mathrm{H}_{1,2}$ are the null hypotheses and the alternative hypotheses on Granger causality, mentioning that the null ones signify that there is no influence. The * and ** are the hypotheses stipulating that based on competitiveness, market share in the selected developing countries can be forecast or that based on market share, competitiveness in the selected developing countries can be forecast, respectively; the * and ** hypotheses were tested for the confidence level of $95 \%$. In the last two columns, the values of the $Z$ test are given.

the case of five companies, where it was found that there was the Granger cause in both directions. The results as these are in accordance with the general understandings according to which the growth of market shares automatically also implies greater competitiveness, and vice versa, that profitable companies are market leaders. The expectation that based on market share it is possible to forecast a company's competitiveness was recorded in 34 cases, whereas vice versa - that based on the movement of competitiveness market share can be forecast was only found in 13 cases. Although opposing the prevailing understandings of a broader public, the results like these are yet also expected to a certain extent when we bear in mind the characteristics of the economic ambience of these countries.

Namely, a large number of the successful companies operating in these countries are basically foreign companies, which achieve profitability thanks to the transfer of know-how from the parent countries [22], not through market penetration. It is particularly notable in the sectors that require the application of contemporary technology and technical-technological achievements [23]. This should also be added the fact that these companies are more oriented towards taking the profit to their parent states than towards reinvesting it in penetration to the domestic market. So, this fact can to a certain extent explain the situation why in a small number of the cases the movement of market share can be forecast based on profitability. The situation is somewhat different in the sectors of the footwear industry, knitwear industry, the apparel industry, which is also expected since they belong to the consumer goods and service sectors, so they are oriented towards an increase in competitiveness by increasing market share and the expectation that competitiveness also grows through market penetration. It is characteristic of these three countries that the IT sector is in great expansion and that there are a large number of companies in the domestic ownership. It characteristic of this sector that based on the movement of market share it is possible to forecast the movement of competitiveness, but not vice versa, either, which can be justified by the fact that it is profitable to serve the domestic market, and that profitability also grows with the growth of market share. The nonexistence of causality in the Granger sense of competitiveness to market share can be explained by the fact that these companies are exclusively oriented towards exporting IT services, for which reason the movement of the profitability of these companies is exclusively connected with exports, not with the domestic market penetration.

Given the fact that the research study was carried out on a small number of the available data so as to obtain robust assessments, the bootstrap approach was used in the paper. The application of the bootstrap approach is simple and depends on whether the known forms of the distribution function of portfolio return is with an unknown parameter which is present in it $\theta=\theta(F)$ or not [23]. Depending on this, it is possible to apply a parametric or non-parametric bootstrap method. By using the parametric bootstrap method, 10,000 samples were generated, the size of which is equal to the actual sample of the series, separately for each series. More precisely, the observations are simulated as the vector of the random outcome based on the set of the data $\theta$. This is how 10,000 new simulated samples with 14 observations. Then, the same procedure of the application of the Granger causality test was performed for each company and for each time series, as well as with the real data. The summary account of the tested hypotheses and their possible combinations based on the simulations as per the sectors and in total are presented in table 5. 


\begin{tabular}{|l|c|c|c|c|c|c|c|}
\hline \multicolumn{7}{|c|}{ THE SUMMARY ACCOUNT OF THE RESULTS ON THE BOOTSTRAP SIMULATION } \\
\hline \multicolumn{1}{|c|}{ Sector } & $\mathbf{H}_{\mathbf{0 , 1}}$ and $\mathbf{H}_{\mathbf{0 , 2}}$ & $\mathbf{H}_{\mathbf{0 , 1}}$ and $\mathbf{H}_{\mathbf{1 , 2}}$ & $\mathbf{H}_{\mathbf{1 , 1}}$ and $\mathbf{H}_{\mathbf{0}, \mathbf{2}}$ & $\mathbf{H}_{\mathbf{1 , 1}}$ and $\mathbf{H}_{\mathbf{1 , 2}}$ & $\begin{array}{c}\text { Sum of } \\
\text { comp. }\end{array}$ & Hypoth.* & Hypoth.** $^{*}$ \\
\hline The wool industry & 67807 & 43521 & 2589 & 1683 & 115600 & -321.735 & -80.910 \\
\hline The carpet industry & 73691 & 30568 & 30964 & 12281 & 147504 & -166.579 & -168.642 \\
\hline The knitwear industry & 80012 & 34230 & 20303 & 4781 & 139326 & -246.375 & -171.737 \\
\hline The footwear industry & 1358 & 376 & 6389 & 1830 & 9953 & 63.020 & -57.547 \\
\hline The artificial fiber industry & 108.327 & 12824 & 7.128 & 934 & 129.213 & -321.860 & -290.162 \\
\hline The apparel industry & 59.914 & 66.217 & 20.971 & 1.001 & 148.103 & -278.407 & -43.219 \\
\hline IT industry & 21356 & 101378 & 9852 & 14635 & 147221 & -263.782 & 213.391 \\
\hline Total & 412465 & 289114 & 98196 & 37145 & 836920 & -637.376 & -219.910 \\
\hline
\end{tabular}

Note: $\mathrm{H}_{0,1}, \mathrm{H}_{0,1}, \mathrm{H}_{0,2}, \mathrm{H}_{1,2}$ are the null and the alternative hypotheses on Granger causality, mentioning that the null ones signify that there is no influence. The * hypotheses were tested for the confidence level of $95 \%$. In the last two columns, the values of the Z-test are given.

The results based on the simulation do not fully confirm the conclusion drawn based on the analysis of the data in table 4. Namely, the results based on the simulation indicate that it can generally be said that it is impossible to forecast the movement of the market share of these enterprises on the basis of the movement of a series of competitiveness (profit rate) data of the enterprises from within the selected sectors, and vice versa, on the markets of the tested countries.

\section{CONCLUSIONS}

The paper dealt with doing research in the existence of causality in Granger's sense between competitiveness and market share, and vice versa, on emerging markets so as to answer the question whether it is possible to forecast the movement of the market share of an enterprise based on the data about the movement of the profit rate of that enterprise, and vice versa, or not. The research study was carried out on the example of 96 companies from Serbia, Montenegro, and Bosnia and Herzegovina. These countries had been selected as the adequate representatives of emerging markets given the fact that they have a series of common characteristics. Because of the protection of the data, the data of only those enterprises with respect to which the authors obtained consent. On that occasion, the authors were careful to present those data that adequately and truly represent the results of the overall analysis in a sense that the selected representative best reflects the prevailing characteristics and the findings that are true for the majority of the enterprises from within this sector, and also to simultaneously safeguard the relationship between the sectors and to represent the results of the overall analysis through the selected representatives in as a realistic manner as possible.
The results of the research are to a certain extent in compliance with certain individual research studies, the mention of which has already been made in the introductory parts of the paper - although market share and competitiveness seem to be positive on average, this relationship is generally weak. In other words, the research results reveal that the existence of causality in Granger's sense between competitiveness and market share on the selected emerging markets depends on the branch of textile industry. They point at the existence of causality between competitiveness and market share in the apparel sector and the IT sector, or between market share and competitiveness in the carpet industry, mentioning that when speaking about causality in this paper causality is always implied as causality in Granger's sense. Also, the results of the research are indicative of the fact that it cannot generally be said whether it is possible to forecast the movement of the profit based on the movement of market share, and vice versa, on these markets. In other words, in the majority of the examined series no existence of a causal connection between these two data series has been found. The results based on the simulation by the bootstrap method fully confirm the previously presented conclusion.

It is recommended that future researchers should include a larger number of enterprises from the selected countries in analysis, mentioning that it is an almost impossible work to do when the availability of the needed data is taken into consideration.

\section{ACKNOLEDGEMENTS}

This paper is part of the research project financed by the Ministry of Education, Science and Technological Development of the Republic of Serbia.

\section{REFERENCES}

[1] Miletic, S., Istraživanje koje se odnosi na novi proizvod, In: Ekonomika, 2010, 56, 3, 21-32

[2] Schoeffler, S., Buzzell, R.D., Impact of Strategic Planning on Profit Performance, In: Harvard Business Review, $1974,52,2,137-145$ 
[3] Buzzell, R.D., The PIMS program of strategic research: A retrospective appraisal, In: Journal of Business Research, 2004, 57, May, 478-483

[4] Newton, J.K., Market share: Key to higher profitability?, In: Long Range Planning, 1983, 16, 1, 37-41

[5] Hamermesh, R.G., Anderson, M.J., Strategies for Low Market Share Businesses, In: Harvard Business Review, 1978, 56, 3, 95-102

[6] Chawla, S.K., Khanna, D., Chen, J., Are small business critical success factors same in different countries, In: SIES Journal of Management, 2010, 7, 1, 1-12

[7] Chandler, G.N., Hanks, S.H., Measuring the performance of emerging businesses: A validation study, In: Journal of Business Venturing, 1993, 8, 5, 391-08

[8] Boulding, W., Staelin, R., Environment, Market Share, and Market Power, In: Management Science, 1990, 36, 10, 1160-1177

[9] Jacobson, R., Unobservable Effects and Business Performance, In: Marketing Science, 1990, 9, 74-85

[10] Wensley, R., Explaining Success: The Rule of Ten Percent and the Example of Market Share, In: Business Strategy Review, 1997, 8, 1, 63-70

[11] Schmalensee, R., Do Markets Differ Much?, In: American Economic Review, 1985, 75, June, 341-52

[12] Mueller, D.E., Profits in the Long Run, Cambridge University Press, Cambridge, 1986

[13] Yannopoulos, P., The Market Share Effect: New Insights from Canadian Data, In: The Journal of Global Business Management, 2010, 6, 2, 257-267

[14] Faria, J., Wellington, W., Validating business simulations: does high market share lead to high profitability?, In: Developments in business simulation and experiential learning, 2004, 31, 332-336

[15] Amburgey, T.L., Dacin, T., Kelly, D., Disruptive Selection and Population Segmentation: Interpopulation Competition as a Segregation Process, In: Baum, J.A.C., Singh, J. V., (Eds.), Evolutionary Dynamics of Organizations, Oxford University Press, New York, 1994

[16] Sheth, J.N., Sisodia, R.S., The Rule of Three: Surviving and Thriving in Competitive Markets, The Free Press, New York, 2002

[17] Genchev, E., Effects of market share on the bank's profitability, In: Review of Applied Socio-Economic Research, 2012, 3, 1, 87-95

[18] Etale, L., Bringilarz, P., Ifuruezes, M., Market Share and Profitability Relationship: A Study of the Banking Sector in Nigeria, In: International Journal of Business, Economics and Management, 2016, 3, 8, 103-112

[19] Goddard, J., Tavakoli, M., Wilson, J.O.S., Determinants of profitability in European manufacturing and services: evidence from a dynamic panel model, In: Applied Financial Economics, 2005, 15, 18, 1269-1282

[20] Pattitoni, P., Barbara Petracci, B., Spisni, M., Determinants of profitability in the EU-15 area, In: Applied Financial Economics, 2014, 24, 11, 763-775

[21] Leverty, K.G., Market share, profits and business strategy, In: Management Decision, 2001, 39, 8, 607-617

[22] Radivojevic, N., Sabot-Matic, Z., Mirjancic, B., New Historical bootstrap value at risk model, In: Journal of risk model validation, 2017, 11, 4, 57-75

[23] Simonovic, Z., et al., Some problems of small and medium enterprises in Serbian agricultural, In: Anali Ekonomskog fakutletu u Subotici, 2017, 37, 57-69

\section{Authors:}

\section{NIKOLA V. ĆURČIĆ ${ }^{1}$, NIKOLA RADIVOJEVIĆ ${ }^{2}$ ALEKSANDAR GRUBOR ${ }^{3}$, ZORAN D. SIMONOVIĆ 1}

${ }^{1}$ Institute for Agricultural Economics in Belgrade, Volgina no. 15, 11000, Belgrade, Serbia e-mail: zoki@medianis.net

${ }^{2}$ Technical college at applied studies, Kosovska no. 8, 34000, Kraguejvac, Serbia e-mail: radivojevic034@gmail.com

${ }^{3}$ University of Novi Sad, Faculty of Economics in Subotica, Segedinski put no. 9-11, 24000, Subotica, Serbia e-mail: agrubor@ef.uns.ac.rs

Corresponding author:

NIKOLA ĆURČIĆ

e-mail: nikolavcurcic@yahoo.com 